University of Nebraska - Lincoln

DigitalCommons@University of Nebraska - Lincoln

$1-17-2020$

The Enigmatic Spelaeorhynchidae Oudemans, 1902 (Acari:

Mesostigmata) Blood-Feeding Ectoparasites Infesting Neotropical Bats, with Catalog and Notes on a Collection from the Manú Biosphere Reserve in Peru

\author{
Donald Gettinger \\ Harold W. Manter Laboratory of Parasitology, donaldgettinger@gmail.com \\ Madalyne Epperson \\ University of Nebraska-Lincoln \\ Candy Hermasillo \\ University of Nebraska-Lincoln \\ Scott Gardner \\ University of Nebraska-Lincoln, slg@unl.edu
}

Follow this and additional works at: https://digitalcommons.unl.edu/manter

Part of the Biodiversity Commons, Parasitology Commons, and the Zoology Commons

\begin{abstract}
Gettinger, Donald; Epperson, Madalyne; Hermasillo, Candy; and Gardner, Scott, "The Enigmatic Spelaeorhynchidae Oudemans, 1902 (Acari: Mesostigmata) Blood-Feeding Ectoparasites Infesting Neotropical Bats, with Catalog and Notes on a Collection from the Manú Biosphere Reserve in Peru" (2020). MANTER: Journal of Parasite Biodiversity. 12.

https://digitalcommons.unl.edu/manter/12
\end{abstract}

This Article is brought to you for free and open access by the Parasitology, Harold W. Manter Laboratory of at DigitalCommons@University of Nebraska - Lincoln. It has been accepted for inclusion in MANTER: Journal of Parasite Biodiversity by an authorized administrator of DigitalCommons@University of Nebraska - Lincoln. 


\title{
The Enigmatic Spelaeorhynchidae Oudemans, 1902 (Acari: Mesostigmata) Blood-Feeding Ectoparasites Infesting Neotropical Bats, with Catalog and Notes on a Collection from the Manú Biosphere Reserve in Peru
}

\author{
Donald Gettinger, Madalyne Epperson, Candy Hermasillo, and Scott Gardner
}

Harold W. Manter Laboratory of Parasitology, University of Nebraska-Lincoln, Lincoln, Nebraska, USA

Corresponding author — Donald Gettinger, email donaldgettinger@gmail.com

\begin{abstract}
A survey of ectoparasites associated with bats collected along an elevational transect in the Manú Biosphere Reserve, Peru, includes specimens of two species of an unusual and rarely collected family of parasitic mites, the Spelaeorhynchidae Oudemans, and reveals information on the natural occurrence of these infections. In lowland rainforest (450-1,000 m) along the Rio Alto Madre de Dios, Spelaeorhynchus soaresi Peracchi was recorded exclusively infecting two species of frugivorous Carollia, C. brevicauda and C. perspicillata. At higher elevations in the mountains and cloud forests, Spelaeorhynchus praecursor Neumann exclusively infected two species of nectarivorous Anoura, A. cultrata and A. geoffroyi. The consistency of both altitudinal and host distributional limits between sampling periods suggests that the true focus of infection may be sustained in certain habituated, long-term roosting sites. This valuable spelaeorhynchid survey collection (slides and vials) is available for further study at the following repositories: the Harold W. Manter Laboratory of Parasitology, University of Nebraska-Lincoln, and the Field Museum of Natural History, Chicago.
\end{abstract}

Keywords: bats, ectoparasites, Acari, Spelaeorhynchidae, Spelaeorhynchus, nidality

From these data it would seem that the tick is not very common, perhaps being of seasonal occurrence and local distribution.

Irving Fox, Puerto Rico, 1942

\section{Introduction}

Female spelaeorhynchid mites are blood-feeding ectoparasites of neotropical bats. They pass their adult life in a fixed position on the host, feeding on blood and reproducing through viviparity, sequentially gestating a single egg/larva. However, neither male nor nymphal instars have been described. Up to the current time, all known specimens have been collected as adult females that when found are firmly attached to the skin of the host. Nothing is known about how or where these bats become infected nor which developmental stage of the mite is the actual infective form. Smaller females are assumed to be younger, and although a single "deutonymph" has been described (Dusbábek, 1970), it is possible that this specimen is actually a 
teneral female. Presumably, either the deutonymph, or the newly eclosed female is the infective stase.

Because adult female spelaeorhynchids are caducous, quickly losing the terminal ambulacra after attachment, they are then no longer capable of active dispersal. However, with their permanent access to a rich and reliable food resource (host blood), these females have the potential of a long life producing viable offspring. The intrauterine larva is large, with long legs, each bearing an ambulacrum, typical of species of Mesostigmata, with large paired claws and medial empodium. This strong larva appears well prepared to pursue a free-living habit, or to simply disperse and then undergo further development as an elattostase in some off-host environment. The complete spelaeorhynchid life history remains unknown and shrouded in mystery.

\section{Taxonomic status of the genus Spelaeorhynchus Neumann, 1902}

The taxonomic history of the species allocated to the genus Spelaeorhynchus is detailed thoroughly elsewhere (Fain et al, 1967; Hoffman and Barrera, 1970; Peracchi, 1990); the early and insightful establishment of the monobasic family Spelaeorhynchidae Oudemans, 1902 recognizes both the distinctiveness of these mites and their lack of affinities with the Ixodidae. However, because our understanding of these mites is based almost entirely on the study of a limited number of specimens scattered in research collections around the world, relatively few specimens have been compared critically across hosts and geography. Many of the morphological characters utilized to differentiate taxa within the Spelaeorhynchidae appear inadequate for describing their divergence at the species level (Hoffman and Barrera, 1970), and this results in a long list of synonymies under $S$. praecursor Neumann (see species account). Mites included in the Spelaeorhynchidae have traditionally been included within the Dermanyssoidea, but molecular data suggest placement in the Eviphidoidea along with the sister family Spinturnicidae (Dowling and OConnor, 2010).

Spelaeorhynchid taxonomy has been based exclusively on the morphology of the parasitic adult female stage, collected while embedded on the host bat. As a permanent parasite on a long-lived mammalian host, specimens that have been collected and described vary greatly in reproductive condition including forms that are nongravid, or with an egg or with a larva, and also in reproductive history (nulliparous to multiparous). This morphological age variation may be driven both by neosomy (the adding of new cuticle within the same developmental stage) and teratologies. New cuticle can be added to the surface of the podosomal shield, obscuring patterns of sculpturing, or added to the edge of the shield, changing size and form (Audy et al., 1972). Damage to attached mites caused by grooming by the host is probably another source of intraspecific variation of mensural and meristic measurements because many setae on the body are often missing and/or broken.

Following Peracchi (1990), we recognize six named species in the family, three with a triangular sternal shield (including the second sternal setae) and modified spatulate setae on the palps (Figures 1 and 2), the "praecursor-group" (S. praecursor, S. monophyly, and S. chilonycteris), and three with a straplike sternal shield (excluding the second sternal seta) and modified spiniform setae on the palps (Figures 3 and 4), the "soaresi-group" (S. jimi, S. soaresi, and S. wenzeli). Until Peracchi's dissertation, apparently only the S. praecursor morphology was known. Although he described 3 new species, including S. jimi, S. soaresi, and S. wenzeli, for the reasons listed above the morphological characters used to define and compare spelaeorhynchid mites remain problematical.

The mites we have recorded infecting bats of the genus Anoura fit well within the description of S. praecursor and are easily separated from the mites infecting Carollia by two clear morphological characteristics. In S. praecursor, the sternal shield is distinctly triangular in shape and evenly sclerotized, widest at the anterior margin and narrowing to end at the level of coxae III; with S. soaresi, the anterior edge of the sternal shield is more strongly sclerotized than the posterior region, forming a narrow, straplike shield which merges laterally with the exopodal plates tending coxae I, thus forming a transverse line of locking shields ventrally between the attached camerostome of the feeding mite and the hysterosoma posterior to coxae II. In both forms, the three pairs of sternal setae and two pairs of pores are present, with the first pair of pores displaced laterally near the junction with the exopodal plates. The palps of spelaeorhynchid mites bear 5 free segments; the trochanter extends ventrally below the adjacent femur, preventing downward movement of the palps. Both S. praecursor and S. soaresi display modified setae on the leading edge of the trochanter, femur, and genu; these distinctive sensory setae are spatulate in praecursor forms and are spiniform in the soaresi forms. 


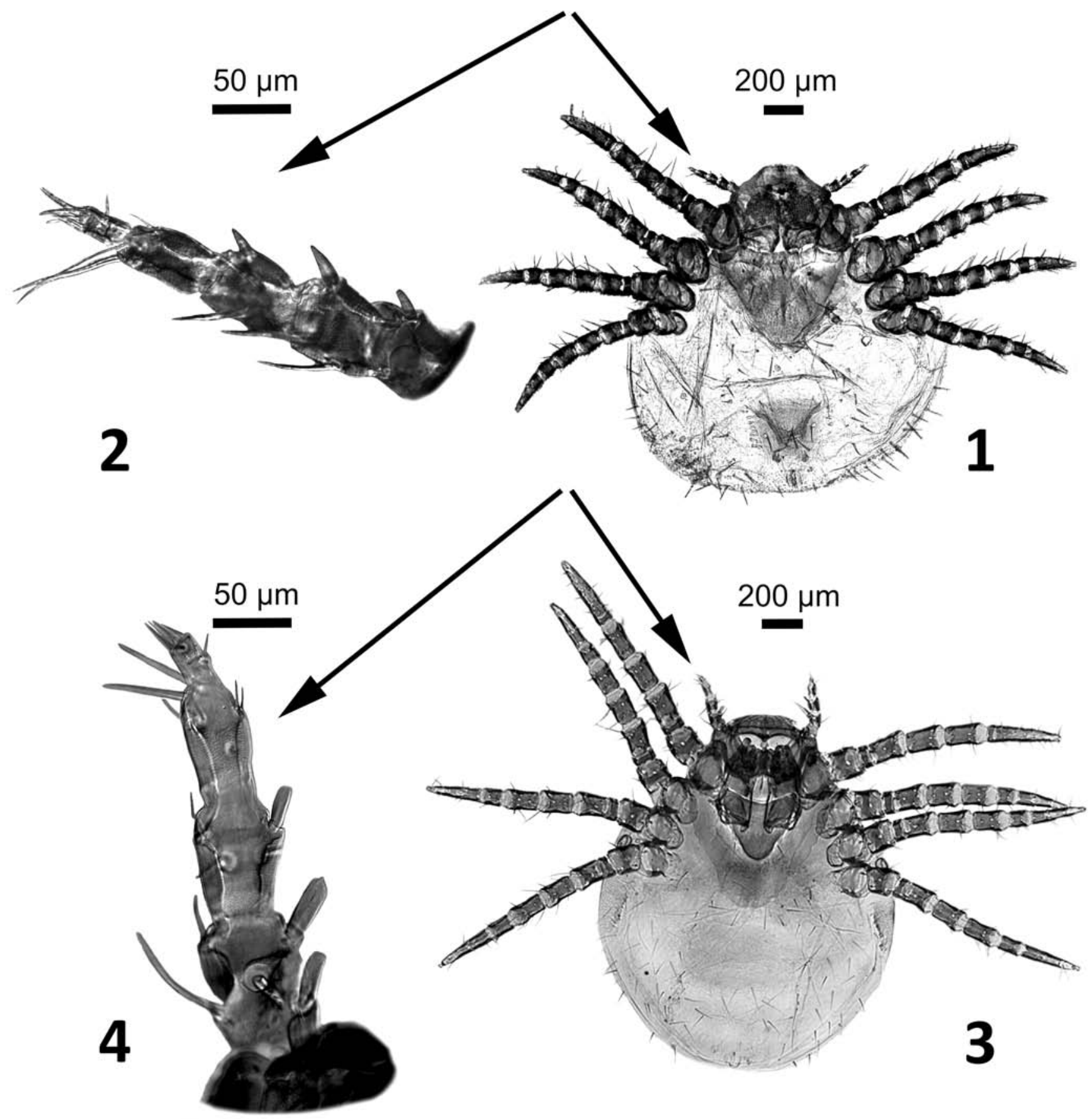

Figures 1-4. (1) Spelaeorhynchus praecursor Neumann, adult female. (2) Left pedipalp with anterolateral setae of trochanter, femur, and genu blunt and flattened. (3) Spelaeorhynchus soaresi Peracchi, adult female. (4) Left pedipalp with anterolateral setae of trochanter, femur, and genu spiniform.

Spelaeorhynchid mites seem to prefer phyllostomid bats as hosts, with most existing host records from stenodermatines, carollines, and glossophagines. S. chilonycteris Fain, Anastos, Camin \& Johnston was very minimally described from a single female mite associated with a mormoopid. Carollia brevicauda and C. perspicillata are both recorded in the literature as hosts of $S$. praecursor, although they are both primary hosts for $S$. soaresi in the Manú Reserve. 


\section{Materials and Methods}

From 1999 to 2001, an elevational survey of bats and their associated ectoparasites was carried out within the Manú Biosphere Reserve, an UNESCO World Heritage site in Peru. This large protected area is located in the tropical Andes (ca. $11^{\circ} 17^{\prime}-13^{\circ} \mathrm{S}, 71^{\circ} 10^{\prime}-72^{\circ} 22^{\prime} \mathrm{W}$ ) in a region considered one of the most biodiverse in the world. The survey and conservation effort was led by a team of field biologists organized by the Field Museum of Natural History, Chicago (FMNH). Bats and ectoparasitic arthropods were collected along an altitudinal transect from the lowland forests at the bank of the Río Alto Madre de Dios to high on the eastern slopes of the Andes. Camps were set at the following collecting localities: Madre de Dios, Quebrada Aguas Calientes ( $450 \mathrm{~m}$ ); Madre de Dios, Maskoitania ( 480 m); Cuzco, Consuelo ( 1,000 m); Cuzco, San Pedro $(\sim 1,480 \mathrm{~m})$; Cuzco, Suecia $(\sim 1,920 \mathrm{~m})$; Cuzco, Pillahuata ( 2,460 m); Cuzco, La Esperanza ( 2,880 m); and Cuzco, Puesto de Vigilancia Acjanaco ( 3,450 m). Bats were captured, primarily using mist nets, and returned to a mobile field laboratory where they were individually anaesthetized, examined, and sampled for ectoparasites. Arthropods were preserved in carefully labeled vials of ethanol, linking each sample to a museum voucher specimen of the host individual. This survey was designed to limit or eliminate data errors and problems that arise from cross-contamination of one sample with the ectoparasites of another. All collected bats were accessioned into the Mammal Collection of the Field Museum of Natural History, Chicago; host identifications can be verified and updated online by searching the FMNH catalog numbers. More information on the Manú Biosphere Reserve, the surveys, and fauna may be found in Solari et al., 2006 and Patterson et al., 2006.

This taxonomic species catalog presents survey data and observations based upon the identification of all spelaeorhynchid mites and also provides descriptive information about the collections and their repositories. Because the formal identification of representative specimens mounted on slides served as the basis for determination of the remaining material preserved in vials of alcohol, this collection remains a valuable source of comparative material for further research on Neotropical spelaeorhynchid mites. The synoptic collections of identified slide material are available for further study at the H. W. Manter Laboratory of Parasitology (HWML) and the FMNH. The research collection of voucher specimens in alcohol was also deposited in both institutions.

\section{Specimens examined}

Each recorded collection locality from the Manú altitudinal transect is followed by a list of collection records in which are included host species, host field number, host sex (reproductive condition), and voucher specimen preparation (ssk = skin, full skeleton; ssa = skin, skull; sko = skin only; alc = fluid specimen). Each host collection record datum is followed by information on the spelaeorhynchid mites in brackets: [number of female mites (reproductive condition)].

\section{Taxonomic Catalog}

Spelaeorhynchus Neumann, 1902

Type species: Spelaeorhynchus praecursor Neumann, 1902

\section{Species accounts:}

Spelaeorhynchus praecursor Neumann, 1902, see pages 31-37; Neumann, 1906: 220; Neumann, 1911: 136, figs. 71-76; Banks, 1915: 70, fig. 133; Vigueras, 1956: 53; Aragao and Fonseca, 1961: 120; Taboada, 1965: 10; Machado-Allison, 1967: 369; Fain et al., 1967: 542-549, figs. 1, 2, and 4-13; Dusbábek, 1970a: 273; Dusbábek, 1970b: 258-261, 5 figs.; Tamsitt and Fox, 1970: 1093-1094.

Spelaeorhynchus latus Banks, 1917; Fonseca, 1935; Fonseca, 1937; Fox, 1942; Radford, 1950; Fonseca, 1958; Taboada, 1965; Machado-Allison, 1967.

Spelaeorhynchus cubanus Dias, 1958 (see Dusbábek, 1970).

Type locality: Brazil, Pernambuco

Type host: Carollia brevicauda (Schinz, 1821)

Remarks: Although S. praecursor is more commonly reported from stenodermine and glossophagine bats, Carollia spp. often share roosts with these bats.

Locality: Peru, Cusco Province: Suecia, Km 138.5 Carretera Shintuya, $13^{\circ} 6^{\prime} 8.1^{\prime \prime} \mathrm{S} ; 7^{\circ} 34^{\prime} 2.9994^{\prime \prime W}, 1,900-2,100 \mathrm{~m}$. Specimens examined: 17 September 1999: From Anoura geoffroyi; JAA\#420 (169852), female (lactating), ssk [1F]. 19 September 1999: From A. geoffroyi, JAA\#434 (16984), male (scrotal), sko [1F]; from Anoura cultrata, BDP\#3791 (169829), male (abdominal), ssk [1F]. 21 September 1999: From A. geoffroyi, SS\#1881 (169831), female, alc. [1F]; LLW\#665 (169853), female, ssk [1F]. 
Locality: Peru, Cusco Province: La Esperanza, 39 km by road NE Paucartambo, 12¹0'39.7194"S; 71³6'16.2"W, 2,850-3,240 m.

Specimens examined: 27 October 2001: From Anoura geoffroyi, UPE\#259 (174520), female (lactating), ssa [2F]. 29 October 2001: From A. geoffroyi, ESG\#157 (174524), female (lactating), ssa [1F]. 3 November 2001: From $A$. geoffroyi, UPE\#288 (174516), female (lactating), alc [1FS, 1FV]. 4 November 2001: From A. geoffroyi, BDP\#4182 (174527), female, ssk [2F].

Spelaeorhynchus soaresi Peracchi, 1990: 20-21

Type locality: Peru, Puno, Segrario

Type host: Carollia sp.

Remarks: There is a wide range of mensural variation among mite individuals is this collection.

Locality: Peru, Cusco Province: Quebrada Aguas Calientes, $2.75 \mathrm{~km}$ by road E Shintuya, left bank of the Rio Alto Madre de Dios, $12^{\circ} 40^{\prime} 5.88^{\prime \prime} \mathrm{S} ; 71^{\circ} 15^{\prime} 36^{\prime \prime} \mathrm{W}, 450-520 \mathrm{~m}$.

Specimens examined: 25 August, 1999: From Carollia brevicauda; SS\#1759 (169927), female, alc. [1F]; from Carollia perspicillata; BDP\#3645 (169988), male, alc. [1F]; BDP\#3646 (169965), female, alc. [1F]; JAA\#323 (169984), male (abdominal), alc. [1F]; JAA\#326 (169982), male (abdominal), alc. [1F]; PMV\#327 (169892), male, alc. [1F]; PMV\#328 (169959), female, alc. [1F]; PMV\#330 (169979), male (scrotal), alc. [1F]; PMV\#335 (169979), male (scrotal), alc. [1F].

Locality: Peru, Cusco Province: Maskoitania, 13.4 km by road NNW Atalaya, left bank of Rio Alto Madre de Dios; $12^{\circ} 46^{\prime} 18.1194^{\prime \prime} \mathrm{S}^{\prime} 71^{\circ} 23^{\prime} 7.7994^{\prime \prime} \mathrm{W}, 480 \mathrm{~m}$.

Specimens examined: 10 September, 2001: From Carollia perspicillata; UPE\#105, (174627), female, ssa [1F]. 11 September, 2001: From Carollia brevicauda; BDP\#3939 (174585), female, alc. [1F]; from C. perspicillata; SS\#2103 (174618), female, sko [1F]; SS\#2104 (174617), female, sko [1F]. 13 September, 2001:_From C. perspicillata; ESG\#17 (174628), female, ssa [1F]; SS\#2112 (174629), female, ssa [1F]; BDP\#3950 (174635), female, ssk [1F]; BDP\#3951 (174634), male, ssk [1F]. 14 September, 2001: From C. perspicillata; ESG\#22 (174620), female, ssa [1F]; ESG\#28 (174614), female, alc. [1F].

Locality: Peru, Cusco Province: Consuelo, 15.9 km by road SW Pilcopata, 13¹'24.96"S; 71²9'30.6594"W, $1,000 \mathrm{~m}$.

Specimens examined: 3 October, 2001: From Carollia brevicauda; SS\#2166 (174584), female, alc. [1F]; ESG\#73 (174590), male (scrotal), ssa [1F]; ESG\#74 (174593), female, ssa [1F]; SS\#2167(174586), male, ssa [1F]; UPE\#186 (174589), female, ssa [1F]; BDP\#4035 (174596), female, ssk [1F]. 4 October, 2001: From Carollia brevicauda, SS\#2169 (174582), male, abdominal, alc [1F]; UPE\#188 (174580), female, alc. [1F]; C. perspicillata, SS\#2170 (174622), male (abdominal), ssa [1F]. 5 October, 2001: From C. perspicillata, UPE\#193 (174631), male (scrotal), ssa [1F]. 7 October, 2001: From C. perspicillata, UPE\#196 (174623), male (scrotal), ssa [1F]. 10 October, 2001: From C. perspicillata, ESG\#103 (174621), male (scrotal), ssa [1F]. 16 October, 2001: From C. perspicillata, ESG\#124 (174633), male (scrotal), ssk [1F].

\section{Spelaeorhynchidae of the Manú Reserve}

The Manú survey was extensive, with collection localities situated along an altitudinal transect, but collecting was limited in temporal breadth. Between 1999 and 2001, 832 bats represented by 30 genera and 64 species were sampled for ectoparasites. Most of the sampling was done during the seasonal regional forest transition from dry-cool (August/September) to wet-warm (October/November).

In both of these sampling years, spelaeorhynchid mites were detected exclusively in populations of two plant-visiting phyllostomid genera, the frugivorous Carollia and the nectarivorous Anoura. An active nidus of Spelaeorhynchus soaresi was recorded at lower elevation localities (450-1,000 m) infecting Carollia brevicaudata and C. perspicillata. Carollia castanea $(n=28)$ was not infected. A second nidus of infection was detected in both years at higher elevation localities (1,920-2,880 $\mathrm{m})$, where Anoura geoffroyi and A. cultrata, two nectarivorous species were infected with Spelaeorhynchus praecursor. Anoura caudifer ( $\mathrm{n}=15$ ) was not infested. No bats collected at elevations lower than 1,920 m were infected with S. praecursor, and no bats above 1,000 m were infected with S. soaresi.

More careful observation of spelaeorhynchid mites is needed, both in the field and laboratory. As blood-feeding parasites, their role in the transmission of zoonotic disease is as yet unknown and unstudied. The application of landscape epidemiological methods to locate and study the nidality of naturally occurring spelaeorhynchid infections in the field as well as laboratory experimental studies will be necessary to understand the significance of these important parasites of bats. 


\section{References}

Audy, R. J.; Radovsky, F. J.; Vercammen-Grandjean, P. H. 1972. Neosomy: radical intrastadial metamorphosis associated with arthropod symbioses. Journal of Medical Entomology 9: 487-494.

Banks, N. 1915. The acarina or mites: a review of the group for the use of economic entomologists. United States Department of Agriculture 108: 1-153, 294 figures.

Banks, N. 1917. New mites, mostly economic. Entomological News, 28: 193-199, 2 plates, 15 figures.

Dias, J. A. T. S. 1958. Notas ixodológicas. V. Acerca de alguns ixodídeos do Museu do Hamburgo. Memorias e Estudos do Museu Zoológico da Universidade de Coimbra 253: 1-32, 5 figures.

Dowling, A. P. G.; OConnor, B. M. 2010. Phylogenetic relationships within the suborder Dermanyssina (Acari: Parasitiformes) and a test of dermanyssoid monophyly. International Journal of Acarology 36: 299-312.

Dusbábek, F. 1970a. New records of parasitic mites (Acarina) from Cuba and Mexico. Mitteilungen aus dem Zoologischen Museum in Berlin 46: 273-276.

Dusbábek, F. 1970b. On the Cuban species of the genus Spelaeorhynchus (Acarina). Acarologia 12: 258-261, 5 figures.

Fain, A.; Anastos, G.; Camin, J. H.; and Johnston, D. E. 1967. Notes on the genus Spelaeorhynchus. Description of $S$. praecursor Neumann and of two new species. Acarologia 9: 535-556.

Fonseca, F. 1935. Notas de acarologia. XVII. Localização, frequencia, distribuição geográfica e hospedadores de Spelaeorhynchus latus Banks, 1917 (Acarina, Spelaeorhynchidae). Memórias do Instituto de Butantan 9: 145-148.

Fonseca, F. 1937. Remarks on the tick "Spelaeorhynchus latus" Banks. Proceedings of the Twelfth International Congress of Zoology 8: 1580-1583.

Fonseca, F. 1958. Geruchsorgane und entwicklungsgeschichte der Mesostigmata und Spelaeorhynchidae (ACari). Memórias do Instituto de Butantan 28: 55-58.

Fox, I. 1942. The occurrence of a rare genus of ticks on bats in Puerto Rico (Acarina, Spelaeorhynchidae). The Journal of Agriculture of the University of Puerto Rico 26: 95-97.
Hoffman, A.; Barrera, I. B. 1970. Acaros de la familia Spelaeorhynchidae. Revista Latinoamericana de Microbiología 12: 145-149.

Machado-Allison, C. E. 1967. Sobre algunos ectoparasitos de Mamíferos de la Biota Amazonica. Atas do Simpósio sobre a Biota Amazonica 5: 365-372.

Neumann, L. G. 1902. Spelaeorhynchus praecursor n.g., n.sp. nouvel acarien parasite. Archives de Parasitologie 5: 31-37.

Neumann, L. G. 1906. Note sur Spelaeorhynchus praecursor. Archives de Parasitologie 110: 220.

Neumann, L. G. 1911. Acarina. Ixodidae. Das Tierreich. Im Auftrage der Preußischen Akademie der Wissenschaften zu Berlin 26: 1-169.

Oudemans, A. C. 1902. In: Verslag van vijf-en-dertigste Wintervergadering der Nederlandse Entomologische Vereniging Tijdschrift voor Entomologie 45: 50-64.

Patterson, B. D.; Stotz, D. F.; Solari, S. 2006. Mammals and birds of the Manú Biosphere Reserve, Peru. Fieldiana Zoology 110: 1-49.

Peracchi, A. L. 1990. Contribuição ao Estudo de Familia Spelaeorhynchidae Oudemans, 1902 (Acarina, Mesostigmata). Revista Brasileira de Zoologia 7: 1-29.

Radford, C. D. 1950. The mites (Acarina) parasitic on mammals, birds, and reptiles. Parasitology 40: 366-394.

Radovsky, F. J. 1985. Evolution of mammalian mesostigmate mites. In: Coevolution of Parasitic Arthropods and Mammals. K. C. Kim (ed.). New York: John Wiley \& Sons, 441-504.

Solari, S.; Pacheco, V. R.; Luna, L.; Velazco, P. M.; Patterson, B. D. 2006. Mammals of the Manú Biosphere Reserve. Fieldiana Zoology 10: 13-23.

Taboada, G. S. 1965. Lista de los parasitos hallados en murciélagos cubanos. Poeyana 12: 1-14.

Tamsitt, J. R.; Fox, I. 1970. Records of bat ectoparasites from the Caribbean region (Siphonaptera, Acarina, Diptera). Canadian Journal of Zoology 48: 1093-1097.

Tamsitt, J. R.; Valdivieso, D. 1970. Observations on bats and their ectoparasites. In: A tropical rain forest: a study of irradiation and ecology at El Verde, Puerto Rico. H. T. Odum and R. F. Pigeon (eds.). U.S. Atomic Energy Commission, Washington, xiv $+1,640 \mathrm{p}$. 